\title{
PERTANIAN BIOINDUSTRI MENINGKATKAN DAYASAING PRODUK AGROINDUSTRI DAN PEMBANGUNAN PERTANIAN BERKELANJUTAN
}

\author{
BIOINDUSTRY AGRICULTURE IMPROVE COMPETITIVENESS OF AGROINDUSTRY \\ PRODUCTS AND SUSTAINABLE AGRICULTURE DEVELOPMENT
}

\section{Roosganda Elizabeth*, Iwan Setiajie Anugrah}

Pusat Sosial Ekonomi dan Kebijakan Pertanian, Jl. Tentara Pelajar No. 3B. Cimanggu Bogor *Email: roosimanru@yahoo.com

(Diterima 30-06-2020; Disetujui 26-07-2020)

\begin{abstract}
ABSTRAK
Penggunaan bioenergi dalam agroindustri diprediksi mampu mengefisienkan dan mengefektifkan pemakaian BBM dan gas serta GMP produk olahannya, serta mampu menerapkan konsep biorefinery untuk menghasilkan bahan pangan dan nonpangan bernilai ekonomis, meminimalisir input energi (konsep zero waste). Tulisan ini bertujuan mengemukakan secara komperehensif pentingnya pengimplementasian pertanian bioindustri dan pemberdayaan kelembagaan terkait untuk peningkatan dayasaing produk agroindustri demi tercapainya pembangunan pertanian berkelanjutan. Pemaparan dilakukan dengan metode deskriptif kualitatif, yang diperkaya dengan review berbagai hasil kajian dan literatur terkait lainnya. Tercapainya pemanfaatan SDA dan SDM dalam pelaksanaan program pertanian bioindustri berkelanjutan untuk mewujudkan kemandirian dan ketahanan pangan, selain memenuhi kriteria GMP. Pengimplementasiannya seharusnya juga mencakup keuntungan: ekonomi, sosial, kelestarian SDA dan lingkungan (SDGs), secara bijak dan berkelanjutan. Perlunya implementasi pengelolaan SDA dan SDM, pemberdayaan peran kelembagaan, efisiensi dan efektifitas energi alternatif dan terbarukan, sebagai penghasil produk agroindustri berdayasaing. Perlunya keberpihakan regulasi dan kinerja program pembangunan yang holistik dan terstruktur terkait regulasi, infrastruktur dan kelembagaan lainnya serta tepat: jenis, waktu, jumlah dan sasaran. Dengan pertambahnya pendapatan dan kesejahteraan para petani, diharapkan mampu mewujudkan kemandirian pangan dan energi, ketahanan pangan serta pertanian bioindustri berkelanjutan.
\end{abstract}

Kata kunci: biorefinery, partisipasi, energi alternatif terbarukan, ketahanan pangan

\section{ABSTRACT}

The use of bioenergy in agroindustry is predicted to be able to make efficient and effective use of fuel and gas and GMP of its processed products, and to be able to apply the concept of biorefinery to produce food and non-food items of economic value, minimizing energy input (zero waste concept). This paper aims to put out comprehensively the importance of implementing bioindustrial agriculture and related institutional empowerment to increase competitiveness of agroindustrial products for the achievement of sustainable agricultural development. The presentation was carried out using a qualitative descriptive method, which was enriched by a review of various study results and other related literature. The achievement of the utilization of natural resources and human resources in the implementation of sustainable bioindustry agriculture programs to realize food independence and security, in addition to meeting the GMP criteria. Implementation should also include benefits: economic, social, natural resources and environmental sustainability (SDGs), wisely and sustainably. The need for the implementation of the management of natural resources and human resources, the empowerment of the role of institutions, efficiency and effectiveness of alternative and renewable energy, as a producer of agro-industrial products. The need for a alignment of regulations and a holistic and structured development program performance related to regulations, infrastructure and other institutions as well as appropriate: type, time, number and target. With the increase in income and welfare of 


\section{PERTANIAN BIOINDUSTRI MENINGKATKAN DAYASAING PRODUK AGROINDUSTRI \\ DAN PEMBANGUNAN PERTANIAN BERKELANJUTAN \\ Roosganda Elizabeth, Iwan Setiajie Anugrah}

farmers, it is expected to be able to realize food and energy independence, food security and sustainable bio-industrial agriculture.

Keyword: Biorefenery, participation, renewable alternative energy, food security

\section{PENDAHULUAN}

"Terwujudnya sistem pertanianbioindustri berkelanjutan yang menghasilkan beragam pangan sehat dan produk bernilai tambah tinggi dari sumberdaya hayati dan kelautan tropika", merupakan visi utama pembangunan pertanian berbasis pertanian bioindustri berkelanjutan yang tercantum dalam dokumen Strategi Induk Pembangunan Pertanian (SIPP) 2015-2045 (Roren, 2014). Dalam pelaksanaan visi tersebut diterapkan konsep biorefinery yang mengoptimalkan konversi biomassa yang meminimalisir input energi dan konsep zero waste untuk menghasilkan bahan pangan dan nonpangan yang bernilai ekonomis tinggi (Elizabeth, 2018). Akselerasi pelaksanaan sistem dan konsep pertanian-bioindustri terkait erat dengan terdapatnya minimal lima tantangan sektor pertanian saat ini, yaitu: 1) peningkatan pendapatan mayoritas petani berlahan $<0,5$ hektar; 2) tantangan agronomis dalam meningkatkan produksi komoditas pertanian terutama pangan; 3) tantangan demografis, dalam memenuhi kebutuhan pangan penduduk yang terus bertumbuh; 4) tantangan menghadapi anomali iklim global dalam mewujudkan pertanian berkelanjutan; 5) tantangan dalam memfasilitasi proses transformasi perekonomian nasional dari berbasis fosil ke bioekonomi. Terkait tantangan tersebut, dibutuhkan penanganan yang holistik dan terintegrasi seluruh pemangku kepentingan dalam menyikapinya, yaitu perubahan dan pembaharuan paradigma pembangunan perekonomian nasional, dari: paradigma pertanian untuk pembangunan (agriculture for development); ke arah (ii) paradigma sistem pertanianbioindustri berkelanjutan.

Indonesia, sebagai negara agraris posisi dan peran pertanian sangat strategis dalam rangka mewujudkan pertanian yang berdayasaing sebagai visi utama pembangunan pertanian, serta mampu mencapai kemandirian dan ketahanan pangan serta energi. Titik lemah perekonomian Indonesia adalah belum optimalnya pergerakan di sektor riil yang berdampak pada terbatasnya kesempatan kerja dan berusaha. Ketangguhan sektor pertanian telah terbukti tidak banyak terpengaruh pada 


\section{PERTANIAN BIOINDUSTRI MENINGKATKAN DAYASAING PRODUK AGROINDUSTRI \\ DAN PEMBANGUNAN PERTANIAN BERKELANJUTAN \\ Roosganda Elizabeth, Iwan Setiajie Anugrah}

masa krisis dulu, dan industrialisasi pertanian memiliki keterkaitan yang kuat dengan sektor lain terutama di masa kini, seperti: keterkaitan konsumsi, investasi, dan tenaga kerja (Widowati, 2001; Ridwan et al, 2008). Agroindustri merupakan upaya/ kinerja/proses usaha industri dalam: menambah kapasitas untuk memperbesar volume produksi pertanian; meningkatkan dan mengembangkan hasil pertanian menjadi produk olahan yang lebih bernilai tambah dan beragam, berdayasaing, serta multi utility; dan dimaksudkan untuk mengubah paradigm dan pola pikir (mindset) bahwa sistem pertanian tidak hanya usahatani penghasil bahan konsumsi saja (Stringer, 2009; Spencer et al, 2009; Kasryno, 2013). Dengan metode deskriptif kualitatif, tulisan ini secara komprehensif mengemukakan pentingnya pemberdayaan kelembagaan terkait peningkatan dayasaing produk agroindustri dalam perspektif pertanian bioindustri demi tercapainya pembangunan pertanian berkelanjutan, yang diperkaya dengan review berbagai hasil kajian dan literatur terkait lainnya.

\section{METODE PENELITIAN}

Semakin menipisnya cadangan minyak bumi dan lamanya proses terbentuknya material bahan bakar dari fosil, mengharuskan segera berinovasi menghasilkan energi alternatif dan terbarukan yang telah dihasilkan dari berbagai aplikasi bioindustri. Tercapainya kemandirian dan ketahanan pangan, pemanfaatan SDA dan SDM dalam pelaksanaan program pertanian bioindustri berkelanjutan selain memenuhi kriteria GMP. Pengimplementasiannya seharusnya juga mencakup keuntungan: ekonomi, sosial, kelestarian SDA dan lingkungan (SDGs), secara bijak dan berkelanjutan. Pengembangan agroindustri dalam perspektif pertanian bioindustri mengindikasikan perlunya peningkatan kualitas dan kompetensi SDM dan kelembagaan terkait yang bijak dari aspek ekonomi, sosial dan kelestarian lingkungan (SDGs). Perlunya peran dan pemberdayaan kelembagaan penghasil produk agroindustri berdayasaing, efisiensi dan efektifitas energi alternatif dan terbarukan dengan pengelolaan SDA dan SDM.

Pengembangan sistem pertanianbioindustri berkelanjutan merupakan pelaksanaan konsep bioekonomi, yang transformasinya dilakukan secara luas, namun bertahap dengan level yang berbeda. Terkait hal tersebut, pengem- 
bangan Sistem Pertanian-Energi Terpadu (SPET) menjadi titik berat tahap pertamanya (Bappenas, 2013; Kementan, 2012 dan 2013; dalam Haryono, 2014). Pengembangan SPET juga merupakan strategi untuk meningkatkan kesejahteraan petani kecil dan pengentasan kemiskinan di pedesaan. Selain memungkinkan pengembangan sistem pertanian berkelanjutan, konsep pertanianbioindustri juga memprediksikan pengembangan konsep zero wasted management, dengan mengintegrasikan berbagai aspek sosial ekonomi masyarakat pertanian dan aspek lingkungan. Proses terbentuknya material bahan bakar yang berasal dari fosil butuh waktu yang sangat lama dan semakin menipisnya cadangan minyak bumi mengharuskan manusia untuk segera melakukan berbagai tindakan untuk menghasilkan bahan bakar, substitusi bahan bakar dan sumber energi.

Berbagai kajian bioindustri secara nyata telah mampu menghasilkan berbagai jenis energi terbarukan, terlebih bila dimanfaatkan dalam usaha agroindustri diprediksi mampu mengefisienkan dan mengefektifkan pemakaian BBM dan gas serta GMP produk olahannya.
Dengan metode deskriptif kualitatif, tulisan ini mengemukakan secara lebih komprehensif berbagai usaha dan peluang serta pengembangan bioindustri dan agroindustri yang diperkaya dengan review berbagai hasil kajian dan tulisan serta literatur terkait lainnya. Perlunya pengelolaan SDA dan SDM dari aspek ekonomi, sosial dan kelestarian lingkungan dengan benar dan bijak. Perlunya pembangunan dan pengembangan berbagai infrastruktur terkait dan kebijakan program bantuan sarana peralatan yang tepat jenis dan sasaran agar tercapai tujuan dilaksanakannya program tersebut. Diperlukan berbagai regulasi dan kelembagaan yang mewadahi berbagai kegiatan bioindustri dan agroindustri mulai dari sisi produksi, pengolahan, pemasaran dan keberlanjutannya. Pengembangan usaha bioindustri dan agroindustri, terutama di pedesaan, mengindikasikan adanya peningkatan kualitas dan kompetensi SDM dan tentunya berdampak pada bertambahnya perolehan pendapatan yang disinyalir mampu mewujudkan kemandirian dan ketahanan pangan dan kesejahteraan petani. Dengan demikian, diperolehnya berbagai keuntungan pada konsep sistem pertanian-bioindustri berkelanjutan terse-but karena meman- 
dang lahan bukan hanya SDA, tetapi juga sebagai industri yang memanfaatkan berbagai faktor produksi untuk menghasilkan pangan serta mewujudkan ketahanan dan kedaulatan pangan, energi, serta kelestarian lingkungan dan SDA.

\section{HASIL DAN PEMBAHASAN \\ PENERAPAN \\ TEKNOLOGI \\ BIOENERGI: IMPLEMENTASI PERTANIAN-BIOINDUSTRI}

\section{Pemenuh Kebutuhan Energi}

Energi sangat vital bagi kehidupan dan pemenuhannya berpengaruh besar bagi berlangsungnya berbagai aktivitas ekonomi. Berbagai energi alternatif dan energi terbarukan dapat dihasilkan dari berbagai komoditi pangan, hortikultura, dan tanaman industri lainnya. Dari berbagai tulisan dan hasil penelitian dapat dikemukakan bahwa berbagai produk pertanian dapat diolah menjadi beragam jenis bioenergi, yang dapat dimanfaatkan untuk bahan bakar listrik, sarana transportasi, sumber panas untuk industri dan sebagainya. Bioenergi yang merupakan $60 \%$ dari total energi baru dan terbarukan tidak lagi membutuhkan insentif ekonomi yang tinggi. Pengembangan bioenergi dapat dilakukan pada semua level skala usaha, dimana saja, dan dapat melibatkan semua masyarakat baik pedesaan maupun di perkotaan (semua golongan dan tingkat sosial), terutama di pedesaan dengan kemampuannya menggerakan perekonomian pedesaan.

Ketersediaan biomassa juga sangat berlimpah di Indonesia yang dapat dimanfaatkan untuk menghasilkan biolistrik. Biomassa berpotensi untuk menghasilkan listrik 49.810 MW, yang bila dikonversikan dapat menghasilkan pendapatan sekitar Rp 501,8 T/tahun (harga listrik Rp 1.150/kWh) (ESDM, 2013). Pembangkit listrik berbahan bakar batubara (sekitar Rp 700-800/kWh) juga dilakukan sejalan kebijakan pemerintah untuk meminimalisir ketergantungan BBM sehingga diutamakan dengan proyek percepatan kelistrikan (Hasan, 2014). Pemakaian batubara diprediksi lebih murah sekitar 75\% dibanding pembangkit listrik lainnya (BBM Rp 3200/kWh), dan menghemat sekitar Rp 71,4 T APBN 2014 membiayai BBM untuk listrik PLTD dikonversi ke PLTU yang berbahan bakar batubara (ESDM, 2013). Namun, pemakaian bahan bakar batubara juga menghasilkan 5\% polutan padat (abu= fly ash dan bottom ash), dan disinilah pertanian berperan dengan pemanfaatan fly ash sebagai ameliorant yang memiliki tingkat dan sifat 
kejenuhan basa tinggi serta mengandung unsur hara yang lengkap sehingga dapat meningkatkan $\mathrm{pH}$ lahan gambut dan mampu memperbaiki struktur tanah gambut (Wahyunto, 2005; Liu, et al 2005 dalam_BPPT, 2013).

Dari hasil sintesis minyak sawit diperoleh berbagai jenis surfaktan meliputi DEA (dietanolamida), MES (metal ester sulfonat), APG (alkil poli glikosida), AS (alcohol sulfat), sukrosa ester, dan lainnya. Dulunya, surfaktan diformulasi sebatas produk pembersih (sabun mandi, deterjen), produk kosmetika dan obat-obatan lainnya. Ide untuk meningkatkan produksi minyak bumi dengan memproses surfaktan (yang sebagian besar diimpor) berkembang sejak tahun 2003, yang akhirnya mampu diproduksi melalui kolaborasi riset para ahli perminyakan ITB dan Pertamina (ESDM, 2013). Gliserol (C3H8O3) merupakan hasil samping industri biodiesel dapat dimanfaatkan dalam berbagai usaha bioindustri, diantaranya: sebagai bahan adaptif pada Water Based Mud (WBM) yang meningkatkan lubrisitas lumpur pemboran untuk melumasi dan mendinginkan mata bor secara aktif dan efisien. Gliserol melalui proses esterifikasi asam oleat dengan katalis MESA dikonversi menjadi gliserol ester yang berpotensi digunakan untuk Oil Based Mud (lumpur pemboran berbasis minyak untuk kebutuhan pemboran sumur minyak) (API, 2003 dalam Hambali, 2014).

Sementara itu, biodiesel dari minyak jelantah (minyak bekas) dapat dipergunakan sebagai campuran BBM yang bertujuan untuk mengurangi emisi karbon monoksida dan asap lainnya dari kendaraan. Sementara itu, biopelet merupakan jenis bahan bakar berbasis limbah biomassa (pelepah sawit, bungkil kelapa, sekam, tongkol jagung, kulit kopi, dan sebagainya) yang berpotensi digunakan untuk produksi biopelet). Dengan demikian, bermacam hasil pertanian dan limbah atau sampah yang merupakan buangan dari proses produksi skala kecil hingga besar dapat diolah (bioindustri) menjadi sumber energi yang terbarukan, pupuk organik dan berbagai produk dan kegunaan lainnya.

\section{Pemenuh Kebutuhan Pangan}

Pangan, merupakan kebutuhan pokok yang hakiki dan HAM serta sebagai salah satu sumber penghasil energi, tenaga dan kekuatan bagi setiap mahluk untuk hidup dan beraktivitas setiap harinya. Indonesia memiliki kekayaan SDA hampir di keseluruhan 


\section{PERTANIAN BIOINDUSTRI MENINGKATKAN DAYASAING PRODUK AGROINDUSTRI \\ DAN PEMBANGUNAN PERTANIAN BERKELANJUTAN \\ Roosganda Elizabeth, Iwan Setiajie Anugrah}

wilayahnya dengan dihasilkannya beragam jenis bahan pangan dan komoditi bernilai ekonomi lainnya. Selain beras (sebagai bahan pangan pokok), sagu, sorgum, ubikayu, jagung, merupakan tanaman penghasil karbohidrat pemenuh pangan dan energi, serta bioenergi. Produk bioindustri berbasis jagung sebagai bagian dari teknologi sistem pertanian energi terpadu, selain sebagai sumber pangan berikut berbagai produk hasil olahannya, jagung juga dapat dimanfaatkan sebagai bahan baku pakan (Jumadi, 2008; Mahendradatta, 2008; Iffan, 2010). Limbah jagung juga dapat dioptimalkan sebagai sumber energi yang memberi nilai tambah yang nyata melalui proses olahan. Multiproduct dari jagung, meliputi: (i) food (jagung, jagung pipilan, tepung jagung (maizena), pati jagung, beras jagung instan, grits); (ii) fiber (serat/ampok); (iii) feed (pakan ternak dari klobot, batang, tongkol, dan daun jagung); dan (iv) fuel (bioetanol).

Tanaman sagu merupakan tanaman asli Indonesia yang terdapat dan sangat berpotensi di daerah Papua (90\%), dan di beberapa daerah lainnya (Aceh, Tapanuli, Sumatera Barat, Riau, Kalimantan, Jawa Barat, Sulawesi Utara dan Selatan), dimana zona penyebarannya tidak mencerminkan batas potensi produksinya (Sutisna, 2015). Manejemen bioindustri sagu dimulai dari kriteria bibit yang baik, penjarangan anakan sangat menentukan baik tidaknya pertumbuhan sagu, hingga pengolahan panen sagu yang benar menjadi sangat krusial dan penting untuk memperoleh dan menjaga kualitas dan kuantitas pati sagu (Ihalauw, 2014). Pengembangan budidaya dan bioindustri sagu menghadapi berbagai permasalahan yang harus ditangani secara bijak, seperti: (i) SDA sagu belum dikelola dengan baik salah satunya karena masih sebatas konsumsi keluarga serta masih banyaknya tanaman sagu siap panen dibiarkan kering dan mati; (ii) belum optimalnya mesin produksi pabrik sagu yang disebabkan masih kurang memadainya dukungan energi listrik, masih relatif rendahnya SDM pascapanen dan pengolah, serta tidak sesuainya peralatan pascapanen dan pengolahan; (iii) penebangan pohonnya masih manual; (iv) belum adanya regulasi dan kelembagaan yang mewadahi petani sagu, dari sisi produksi, pengolahan dan pemasaran sagu. 


\section{PROSPEK PENGEMBANGAN PERTANIAN BIOINDUSTRI DAN AGROINDUSTRI}

Untuk melindungi sektor pertanian dari persaingan di pasar dunia dalam rangka mendukung keberhasilan produk olahan hasil agroindustri diperlukan beberapa kebijakan, meliputi: memperjuangkan konsep Strategic Product (SP) dalam forum WTO; (ii) penerapan tarif dan hambatan non-tarif untuk komoditas pertanian yang dianggap sangat sensitive; (e) Kebijakan pengembangan industri yang lebih menekankan pada agroindustri skala kecil di pedesaan dalam rangka meningkatkan nilai tambah dan pendapatan petani; (f) Kebijakan investasi yang kondusif untuk lebih mendorong minat investor dalam sektor pertanian; (g) Pembiayaan pembangunan yang lebih memprioritaskan anggaran untuk sektor pertanian dan sektor-sektor pendukungnya;

Perhatian pemerintah daerah pada pembangunan pertanian meliputi: infrastuktur pertanian, pemberdayaan penyuluh pertanian, pengembangan instansi lingkup pertanian, menghilangkan berbagai pungutan yang mengurangi dayasaing pertanian, serta alokasi APBD yang memadai.

Globalisasi perdagangan meliputi berbagai tantangan yang bervariasi yang hendaknya dimaknai sebagai peluang bagi produk olahan Indonesia untuk dapat bersaing di pasar internasional mencakup: (i) kokohnya pasar domestik produk, supaya tidak hanya dibanjiri produk impor; (ii) penyediaan produk yang aman, higienis, berkualitas tinggi dan terjamin dan harga bersaing; (iii) kontiniutas penyediaan produk dan memadainya dukungan kondisi dan sarana lingkungan (Elizabeth, 2015). Untuk meningkatkan dayasaing produk perdagangan Indonesia, keragaman teknologi pengolahan produk pertanian domestik di setiap daerah harus dapat didayagunakan dan disesuaikan dengan kondisi global sebagai sumber kekuatan dalam pengembangan produk agroindustri yang berdayasaing (Kaniasari, 2012).

\section{Prospek Pengembangan Pertanian Bioindustri}

Bioindustri melalui pemanfaatan dan optimalisasi sorgum untuk penggunaan domestik sebagai bahan pangan, serat, energi (sumber bahan baku bioethanol/energi alternatif), pupuk organik cair, pangan fungsional, serta pakan ternak (1 hektar sorgum cukup untuk pakan 6 ekor sapi penggemukan). Seperti halnya tanaman sorgum di NTT yang menghasilkan 3045 ton batang sorgum dan daripadanya 


\section{PERTANIAN BIOINDUSTRI MENINGKATKAN DAYASAING PRODUK AGROINDUSTRI \\ DAN PEMBANGUNAN PERTANIAN BERKELANJUTAN \\ Roosganda Elizabeth, Iwan Setiajie Anugrah}

diperoleh 15-20 ton nira sorgum yang bila diproses (bioindustri) melalui fermentasi memakai enzim pada suhu optimum (= proses distilasi dengan suhu pemanasan $78-100^{\circ} \mathrm{C}$ dalam distiller) dan purifikasi dapat menghasilkan 1,21,6 ton bioethanol dgn kadar kemurnian 61-95\%, dan CO2 (Nurkholis. et al, 2014). Hampir semua bagian tanaman sorgum dapat dimanfaatkan. Sebagai bahan pangan, sorgum memiliki gizi lebih baik dibanding beras dan singkong (Tabel 1), dan menempati urutan setelah gandum, padi/beras, jagung dan baley. Berbagai makanan dari pengolahan sorgum, seperti: (i) jenis roti tanpa ragi (chapatti, tortilla); (ii) jenis roti dengan ragi (injera, kisia, dosai); (iii) bubur kental (to, tuwu, ugali, bagobe, sankati); (v) bubur cair (ogi, ugi, ambili, edi); (v) makanan camilan (pop sorgum, tape sorgum, emping sorgum); (vi) sorgum rebus (urap sorgum, som); (vii) makanan yang dikukus (couscous, wowoto, juadah-sorgum); dan sebagainya.

Tabel 1. Nilai Nutrisi Sorgum, Beras, Jagung, Singkong, Kedelai

\begin{tabular}{lccccc}
\hline \multirow{2}{*}{ Unsur Nutisi } & \multicolumn{3}{c}{ Kandungan per 100 gram } \\
\cline { 2 - 6 } Kalori (Cal) & Beras & Sorgum & Singkong & Jagung & Kedelai \\
Protein (g) & 360 & 332 & 146 & 361 & 286 \\
Lemak (g) & 6,8 & 11 & 12 & 8,7 & 30,2 \\
Karbohidrat (g) & 0,7 & 3,3 & 0,3 & 4,5 & 15,6 \\
Kalsium (mg) & 78,9 & 73 & 34,7 & 72,4 & 30,1 \\
Besi (mg) & 6 & 28 & 33 & 9 & 196 \\
Posfor (mg) & 0,8 & 4,4 & 0,7 & 4,6 & 6,9 \\
Vit. B1 mg) & 140 & 287 & 40 & 380 & 506 \\
\hline
\end{tabular}

Sumber: Departemen Kesehatan RI (2004) (Nurkholis et al, 2014)

Sebagai bahan industri (bioindustri), biji sorgum mengandung $65-71 \%$ pati yang dapat dihidrolisa menjadi gula sederhana (gula atau glukosa cair atau sirup fruktosa) yang selanjutnya dapat difermentasi untuk menghasilkan alkohol (1 ton biji sorgum dapat menghasilkan 384 liter alkohol). Biji sorgum dapat dibuat pati (starch) yang berwarna putih, yang digunakan industri untuk perekat, bahan pengental, aditif pada industri tekstil, dan hasil sampingannya digunakan sebagai pakan. Pati merupakan bahan utama pada berbagai sistem pengolahan pangan, antara lain sebagai: sumber energi utama, berperan sebagai penentu struktur, tekstur, konsistensi, dan penampakan bahan pangan; serta bisa sebagai pengganti industry pati jagung, namun sedikit kendala dalam pengekstrasiannya karena pengikatan pati sorgum sekitar $35-38 \%$ sedangkan pada jagung sekitar 8-15\%. Hasil bioindustri penting dari biji sorgum lainnya adalah 
bir, dimana bijinya dapat menggantikan baley dalam pembuatan bir. Bioethanol sebagai energi alternatif digunakan untuk: bahan bakar (kadar 95\%, harus murni, fuel grade ethanol) dengan kadar buang gas/karbonmonoksida yang lebih sedikit (Biggs, 1989; Nurkholis et al, 2014).

Bioindustri nanas dan ubikayu menghasilkan nanas kalengan dan tepung tapioka (aci), serta menghasilkan energi biogas dari pengolahan limbah cair tapioka dan pengolahan nanas yang dapat menggantikan sumber energi BBM. Selain itu, limbah padat hasil pabrik nanas dan tapioka dimanfaatkan untuk pakan sapi; kotoran sapi diproses menjadi kompos (pupuk organik) untuk kebun nanas, ubikayu dan tanaman lainnya; dan perusahaannya (PT GGP/Great Giant Pineapple mencanangkan target bersama 30-40-50, yang bermakna mengurangi: BBM $30 \%$, bahan kimia $40 \%$ dan peningkatan hasil produksi 50\% (Krisno, 2014).

Sebagai pakan ternak, nilai nutrisi biji, daun, dan batang sorgum tidak kalah dari jagung dan lebih bersifat suplemen. Batang (mengandung kadar gula yang cukup tinggi, disukai sapi) dan daun sorgum harus dilayukan dulu sekitar 2-3 jam sebelum diberikan kepada ternak. Biji sorgum juga untuk pakan unggas (ayam dan burung puyuh) sebagai pengganti tepung jagung karena memiliki nilai protein yang cukup baik (11\%). Bio-slurry (ampas bigas) pemanfaatannya untuk pertanian, ternak dan ikan. Penggunaannya sebagai pupuk organik tersendiri dan atau dikombinasikan dengan pupuk sintetik secara bijak dan teratur, baik berupa padatan dan cairan. Dapat meningkatkan kesuburan lahan dan mengurangi hama dan penyakit, sehingga berdampak meningkatkan produksi pertanian. Terdapat tiga bentuk bio-slurry, yaitu: fresh, padat, dan cair. Berbagai kegunaan bio-slurry, yaitu: 1) bioslurry fresh, untuk: vermil-kompos, pupuk dasar lahan dan kolam; 2) bioslurry padat, untuk: pupuk dasar lahan dan kolam, campuran pupuk organic, pembersih tanah, campuran media jamur, campuran pakan alternatif non sapi; 3) bio- slurry, untuk: pupuk organic cair, pupuk hayati, pestisida organik, dekomposer, hormone tanaman, pelindung benih, anti bau kandang (Hartanto, 2014).

\section{Pengembangan Agroindustri Berbahan Bakar Bioenergi}

Dalam upaya pengembangan dan peningkatan produk olahan agroindustri 
yang berdayasaing, dibutuhkan peningkatan effisiensi dan mutu produk melalui perbaikan sistem produksi, pasca panen dan pengolahan (GAP dan GMP). Dayasaing produk olahan komoditi pertanian Indonesia masih relatif lemah, karena hanya mengandalkan keunggulan komparatif dari kelimpahan sumberdaya alam dan tenagakerja tak terdidik (cost driven factor), sehingga produk yang dihasilkan didominasi oleh produk primer yang bersifat natural (resources-based dan unskilled-labor intensive) (Elizabeth, 2017). Membanjirnya produk olahan luar negeri, sudah harusnya diartikan sebagai tantangan dan peluang yang harus dihadapi dengan meningkatkan dayasaing produk olahan dengan akselerasi dan pengembangan kinerja agroindustri domestik yang memperbaiki kualitas, kuantitas dan efisiensi produk. Dengan upaya mengurangi impor produk olahan, maka ekspor secara bertahap beralih dari produk pertanian primer (bahan baku) ke produk olahan (John, 2009 dalam Elizabeth, 2017).

Agroindustri yang merupakan kegiatan/usaha industri pengolahan diperlukan dalam mengatasi sifat produk pertanian umumnya mudah rusak (perishable) dan musiman (seasonal), terutama produk hortikultura, menjadi berbagai produk olahan. Untuk mengatasi hasil usahatani yang belum sempat/tidak habis dijual dibutuhkan agroindustri untuk mengolahnya (pemanasan, fermentasi, pengeringan, pendinginan, pengemasan, pengalengan, dan lainnya) supaya tidak rugi karena rusak/busuk, yang tentunya memerlukan biaya tambahan. Hasil panen seharusnya dijual segera sesudah dipanen (terutama komoditi hortikultura). Agroindustri juga diartikan sebagai usaha, proses dan program kebijakan untuk membangun dayasaing produk pertanian, memberdayakan kemampuan dan meningkatkan kinerja SDM untuk melakukannya, berkeadilan dan berkelanjutan guna menjamin ketahanan pangan, serta kesejahteraan masyarakat pertanian (terutama petani), dengan mempertimbangkan kelestarian SDA dan lingkungan. Untuk mengingatkan bahwa sebagian besar penduduk miskin berada dan mencari nafkah di sektor ini, khususnya pertanian dalam arti luas (Kusumawardani, 2012; Badan Kebijakan Fiskal, 2012).

Terdapat enam elemen kunci dalam pengembangan agroindustri pertanian pedesaan, yaitu: 1) aglomerasi perusahaan (cluster); 2) peningkatan nilai tambah (value added) dan mata 
rantai nilai (value chain) (Siddik, 2010); 3) jaringan pemasok dan pelanggan; 4) jaringan infrastruktur ekonomi fisik dan non fisik; 5) pemberdayaan dan pengembangan berbagai unsur/aspek kelembagaan di pedesaan terkait pengembangan agroindustri (kompetensi tenaga kerja/SDM); dan 6) pemasaran, terutama dalam implementasi teknologi inovatif pascapanen, mutlak dijadikan fokus utama dalam perancangan kebijakan pemerintah dan diperlukan untuk terwujudnya agroindustri yang solid dan maju, serta untuk menggerakkan dan mengembangkan perekonomian masyarakat pedesaan (Elizabeth, 2015).

Disamping itu, untuk memperkuat industri komoditi pada sisi usahatani/produsen, pemerintah sudah seharusnya berupaya keras untuk memfasilitasi kerjasama penyediaan input usahatani melalui kerjasama kelompok tani dengan berbagai perusahaan (pelaku usaha) yang terkait saprodi, sehingga kebutuhan saprodi pertanian dapat dipenuhi tepat waktu, tepat mutu dan jumlah, tepat harga serta tepat jenis, hingga ke hilir. Peningkatan dan pengembangan akses petani terhadap informasi harga jual hasil panen. Para petani sebaiknya mengetahui harga jual cabai merah sebelum memutuskan untuk menjual hasil panennya (Bahtiar et al, 2011). Informasi yang diperoleh berasal dari pedagang pengumpul atau melihat perkembangan harga di pasar. Pada saat panen umumnya petani mencari informasi harga di tingkat pedagang setempat dan sesama petani. Pencarian informasi harga dilakukan petani dalam interval waktu (misalnya, seminggu sekali).

Keterbatasan petani terkait relatif lemahnya posisi tawar (bargaining position) tersebut, dapat dikaji pada subsistem antara (middle/tengah) hingga hilir yang terdiri dari pedagang pengumpul dan pedagang besar yang merupakan pelaku utama pemasok untuk pelaku usaha produk olahan. Hal ini lebih disebabkan banyaknya jumlah, keseragaman (bentuk dan kualitas) sesuai dengan spesifikasi yang diinginkan industri pelaku usaha produk olahan serta kontiniutas pasokan bahan baku (Iffan, 2010). Pada subsistem ini, pedagang pengumpul dan pedagang besar merupakan, berfungsi dan berperan serta bertindak supplier bahan baku industri (grower). Pedagang pengumpul dan pedagang besar juga mendistribusikannya ke berbagai 
wilayah lain yang membutuhkannya. Selanjutnya aktivitas sortasi dan perdagangan yang dilakukan oleh pedagang besar penerima pasokan di wilayah mereka (terkait distribusi dan penjualan).

Pengembangan agroindustri dalam rangka peningkatan dayasaing produk olahan dan pengembangan pasar ekspor (global), serta multi utility (keuntungan ganda) (Ridwan, 2012), yaitu: (a) sebagai promosi ekspor dan sekaligus substitusi impor, (b) menciptakan nilai tambah pertanian, (c) menciptakan lapangan kerja industri, dan (d) meningkatnya adopsi teknologi. Peningkatan nilai tambah produk pertanian merupakan salah satu target utama Kementerian Pertanian dalam rangka pengembangan agroindustri, melalui peningkatan produk olahan yang diperdagangkan, pengembangan dan peningkatan produk olahan berbasis hasil pertanian dan bertujuan ekspor untuk memperoleh peningkatan surplus perdagangan luar negeri.

Pengembangan produk olahan agroindustri berbasis pertanian (padi, jagung, kedelai, umbi-umbian), untuk konsumsi, juga sebagai komponen bahan baku kosmetik, industri (tekstil, pewarna/ cat, perekat/lem), pakan ternak, obat-obatan, jamu dan produk olahan turunan lainnya (glukosa, fruktosa, maltodekstrin dan sebagainya) (Elizabeth, 2017). Agroindustri berbasis komoditi perkebunan seperti: kelapa sawit, kelapa, kopi, tebu dan kakao, lada, panili, menghasilkan: $\mathrm{CPO}$ dan PKO (kelapa sawit). CPO merupakan komponen bahan baku produk olahan asam amino, PFAD, vitamin $\mathrm{A}$ dan $\mathrm{E}$, karotan serta olein (hasilnya: minyak goreng, minyak salad, shortening, dan metil esther; produk diturunannya: biodiesel dan surfatin).

Daun kelapa dijadikan atap, serat batang dan akarnya dijalin menjadi tali tambang (untuk kapal dan alat berat) yang sangat kuat, batang kelapa (untuk tiang/jembatan dan perabotan), tempurung/batok kelapa (perkakas/ peralatan/perabotan rumahtangga dan arang), dan lainnya. Produk akhir kelapa yang sudah berkembang dengan baik adalah desiccated coconut (DC), coconut milk/cream (CM/CC), coconut charcoal (CCL), active carbon (AC), brown sugar (BS), nata de coco (ND) dan coconut fiber (CF), virgin coconut oil (VCO) dan coconut wood (CW); dimana industri hilirnya yang terpadu dan berdayasaing berpotensi menghasilkan $\mathrm{CCO}, \mathrm{AC}, \mathrm{CF}$, dan cuka; yang secara 


\section{PERTANIAN BIOINDUSTRI MENINGKATKAN DAYASAING PRODUK AGROINDUSTRI \\ DAN PEMBANGUNAN PERTANIAN BERKELANJUTAN \\ Roosganda Elizabeth, Iwan Setiajie Anugrah}

parsial untuk menghasilkan $\mathrm{VCO}, \mathrm{OC}$, DC, CF, BS dan CW. Hasil agroindustri tersebut mempunyai peluang pasar terbuka; juga seperti: kopi instan, ekstrak kopi, kopi kafein rendah, obatobatan, kosmetik, dll (dari kopi); beberapa produk derivat tebu/PDT (ethanol, ragi roti, inactive yeast, wafer pucuk tebu, papan partikel, papan serat, pulp, kertas, Ca sitrat dan listrik); tepung cake, minyak, dan lemak (olahan kulit dan biji kakao); brand image produk olahan lada dan panili (rempahrempah/spicy); susu dan olahannya (permen, es krim, yoghurt dipasteurisasi).

Produk olahan ternak: sapi (daging dan olahannya: bakso, corned beef, sosis, abon), dan kompos/pupuk organic). Semua jenis komoditi pertanian, perkebunan dan peternakan di Indonesia memiliki fungsi dan peran strategis sebagai komponen dan bahan baku kebutuhan pangan (obat-obatan), sandang (kosmetik), maupun termasuk perkakas, dan perabotan. Hampir semua produk akhir tersebut sudah masuk pasar ekspor dan berkembang cukup baik. Dalam perspektif hukum/regulasi dan kebijakan, sejatinya pemerintah telah mempunyai satu sikap politik ekonomi untuk membangun kemakmuran bangsa terutama di masa yang akan datang (Kemenko Ekuin, 2016). Usaha agroindustri dapat dijadikan sebagai sumber pendapatan sebagian besar penduduk (seiring dengan berkembangnya sektor pertanian primer, sebagai lapangan pekerjaan dan tempat berusaha, yang diharapkan dapat meningkatkan perolehan pendapatan dan mewujudkan kesejahteraan petani. Implementasi akselerasi agroindustri dan tercapainya nilai tambah produk olahan, dapat mendukung pencapaian dayasaing produk dan percepatan pembangunan pertanian di Indonesia. Oleh karena itu, diperlukan revitalisasi kegiatan agroindustri sebagai tindakan terobosan dan strategi serta menjadikannya sebagai lokomotif pertumbuhan ekonomi nasional (Kasryno, 2013 dalam Elizabeth, 2018a).

\section{Peran Penting Regulasi Pendukung}

Agroindustri juga memiliki keterkaitan kuat antar sektor yang tidak hanya keterkaitan produk, tetapi juga melalui keterkaitan konsumsi, investasi, dan tenagakerja. Keterkaitan tersebut karena tenagakerja dan modalnya direalokasikan ke proses pengolahan (dari produk primer menjadi produk olahan) yang dilengkapi analisa kelayakan usaha; yang meliputi: 
keragaan umum, kelayakan finansial, kelayakan ekonomi, kelayakan sosial dan lingkungan, kelayakan teknis, dukungan infrastruktur; dan kebijakan, sebagai data dukung (Rachmat et al, 2012). Berbagai kajian dan penelitian dapat dilakukan untuk mengetahui keuntungan dan kelayakan kinerja agroindustri suatu jenis komoditi pertainan, baik tanaman pangan, hortikultura, perkebunan, peternakan, dan seterusnya. Berdasarkan Permentan No 35/Permentan/OT.140/7/ 2008 tentang Pengolahan hasil pertanian asal tumbuhan adalah mengubah bahan baku menjadi produk primer, setengah jadi atau produk jadi, yang bertujuan: untuk meningkatkan daya simpan ataupun meningkatkan nilai tambah hasil pertanian; serta meminimalisir kerugian karena nilai tambah produk tersebut diambil alih negara lain (Rafki. 2015).

Terkait UU No.13 Tahun 2014 Tentang Perindustrian, beberapa pertimbangan mengenai perlu dan pentingnya pelaksanaan kegiatan usaha produk olahan berbasis hasil pertanian dan pengembangannya, antara lain: (i) sumberdaya alam Indonesia yang kaya dan menyebar rata di seluruh penjuru tanah air, sehingga perlu mendorong usaha industri produk olahan; penciptaan kesempatan kerja seluasluasnya; (iii)meningkatkan nilai tambah (value added); (iv) peningkatan pendapatan yang terkait dengan kesejahteraan pelaku usahatani; (v) membuka peluang ekspor; dan (vi) diyakini akan berdampak dan menciptakan pemerataan pembangunan (Elizabeth, 2017a). Strategi tersebut merupakan sebuah resultante penyikapan secara cerdas bahwa cara pengelolaan SDA harus ditingkatkan dan dikembangkan, sehingga diperlukan implementasi dan akselerasi revitalisasi kegiatan agroindustri (Hadi, 2014 dalam Elizabeth, 2018a). Lahirnya Undang-Undang Nomor 13 Tahun 2014 Tentang Perindustrian tersebut, hendaknya dimaknai sebagai suatu penegasan bahwa sistem industri nasional secara substantif telah memberikan arah pengaturan yang benar tentang pentingnya pembangunan sektor industri berbasis sumberdaya alam (Rafki, 2015).

\section{PERTANIAN BERKELANJUTAN}

BIOINDUSTRI

Beberapa aspek trend yang memiliki konsekuensi dan solusi, terkait pertanian masa depan, yaitu: (i) perlunya upaya mendorong transformasi ekonomi ke bioenergi sebagai antisipasi semakin 
langkanya energi fosil; (ii) semakin urgensi-nya bioproduk, pola hidup sehat, dan pola konsumsi biokultur seiring semakin meningkatnya kebutuhan pangan, pakan, energi dan serat; (iii) perlunya dorongan peningkatan kapasitas adaptasi dan mitigasi untuk mengantisipasi perubahan iklim global; (iv) keharusan pada keniscayaan untuk kegiatan efisiensi dan konservasi sebagai antisipasi dampak terjadinya kelangkaan lahan dan air; (v) pengembangan sistem pertanian ekologis dan bioservices sebagai dorongan dari permintaan terhadap jasa lingkungan hidup; (vi) perlunya penerapan pluriculture sistem biosiklus terpadu sebagai dampak meningkatnya petani marginal; (vii) pengembangan bioekonomi sebagai dampak yang diberikan dari kemajuan Iptek bioscience dan bioengineering.

Paradigma baru pembangunan perekonomian nasional meliputi: 1) paradigma pertanian untuk pembangunan (agriculture for development), yaitu rencana pembangunan perekonomian nasional perlu dirancang dan dilaksanakan sesuai tahapan pembangunan pertanian serta mendudukkan sektor pertanian sebagai motor penggerak transformasi pertanian yang berimbang dan menyeluruh; 2) paradigma sistem pertanian-bioindustri berkelanjutan, dengan pengalihan industri yang berbahan bakar fosil ke bahan bakar terbarukan (hayati). Paradigma ini mendudukkan peran pertanian sebagai penghasil biomassa bahan baku biorefinery untuk menghasilkan pangan, pakan, serat, energi, (food, feed, fiber, energi), dan berbagai bioproduk lainnya, dan lingkungan (environment); yang merupakan isu global pembangunan pertanian yang harus dihadapi sebagai tantangan untuk dapat mengembangkan pertanian ramah lingkungan dengan penerapan teknologi melalui pengembangan bio-science, inovasi menghadapi perubahan iklim (GCC innovation respon), dan bio-informatik yang mengaplikasikan teknologi informasi (bio-information) dengan selalu mengedepankan kelestarian lingkungan dan SDA (Wahyunto, 2005 dalam Hambali, 2004).

Indonesia memiliki berbagai jenis bahan baku yang mampu menghasilkan berbagai jenis bioenergi seperti: biogas, biodiesel, bioetanol, biolistrik dan bioavtur yang dihasilkan dari proses pengolahan lanjutan; yang terus ditingkatkan perolehan dan aplikasi penggunaannya yang pemakaiannya untuk meminimalisir penggunaan BBM. 
Material berbasis pertanian berpotensi besar untuk menjadi bahan baku bioindustri. Pengolahan berbagai produk dan limbah berbasis pertanian yang dapat menghasilkannya, antara lain dari pengolahan: kelapa sawit, jarak, nanas (Krisno, 2014), limbah cair tapioka, kotoran hewan ternak (sapi, kerbau, kuda, kambing, dan ternak lainnya), dari hasil sintesis dan hasil penyulingan berbagai produk berbasis pertanian lainnya.

Dengan telah disusunnya dokumen SIPP (Strategi Induk Pembangunan Pertanian) 2015- 2045 mengenai: "Pertanian-Bioindustri Berkelanjutan Solusi Pembangunan Indonesia Masa Depan" oleh Kementerian Pertanian, sebagai awal pencanangan yang didasari kesadaran akan potensi dan urgensi pengembangan bioekonomi berbasis pertanian, landasan strategis dalam pembangunan pertanian jangka panjang dan mainstreaming perspektif bioekonomi di Indonesia (Kementan. 2013). Untuk mengoptimalkan implementasiannya, visi utama pembangunan pertanian yang berbasis pertanian bioindustri berkelanjutan dijabarkan dalam sembilan misi (Suswono, 2013), yaitu: (i) penataan ruang dan reforma agrarian (RA); (ii) sistem pertanian tropika terpadu; (iii) kegiatan ekonomi produksi, informasi dan teknologi; (iv) pasca panen, agroenergi dan bioindustri berbasis pedesaan; (v) sistem pemasaran dan rantai nilai produk; (vi) sistem pembiayaan pertanian; (vii) sistem penelitian, inovasi dan sumberdaya manusia berkualitas; (viii) infrastruktur pertanian dan pedesaan; dan (ix) program legislasi, regulasi dan manajemen yang imperatif.

Terdapatnya tiga prinsip keberlanjutan sistem pertanian bioindustri, yang meliputi: 1) self financing: membiayai sendiri sebisa mungkin melalui usaha yang saling menunjang dan berjenjang; 2) menerapkan teknologi skala kecil; dan 3) usaha yang layak teknis dan ekonomis (Lidjang et al, 2015). Integrasi sapi perah dengan kelapa sawit yang menghasilkan susu, minyak sawit, biogas (hasil fermentasi kotoran sapi), dan pludge yang merupakan pupuk organik, di Provinsi Aceh dapat dijadikan contoh penerapan tiga prinsip tersebut (Ilham et al, 2018). Terkait ketiga prinsip tersebut, Sistem Pertanian-Energi Terpadu (SPET) yang menjadi titik berat Pembangunan Pertanian-Bioindustri tahap pertama, pada subsistem usahatani primer didasarkan pada inovasi bioteknologi yang mampu menghasilkan biomassa setinggi mungkin untuk dijadikan sebagai 
feedstock penghasil bioenergi; dan untuk mencegah trade-off ketahanan pangan dan ketahanan energi maka SPET pada subsistem bioindustri didasarkan pada inovasi bioengineering untuk mengolah feedstock menjadi energi dan bioproduk, termasuk pupuk untuk usahatani.

\section{Penutup}

Pembangunan pertanian Indonesia sudah seharusnya segera mengantisipasi pengembangan produk olahan melalui akselerasi pelaksanaan agroindustri (industrialisasi pertanian) sehingga ekspor produk pertanian secara bertahap dapat beralih dari produk primer (bahan baku) ke produk olahan (Elizabeth, 2016). Berbagai permasalahan timbul berkaitan dengan kebelummampuan agroindustri domestik terkait upaya pengembangannya untuk menghasilkan produk olahan yang berkualitas dan berdayasaing, keragaman dan tingkat permintaan pasar, disertai oleh kelengkapan regulasi dan peraturan yang berpihak pada petani produsen bahan baku. Terdapat sedikitnya 5 komponen dalam bisnis produk agroindustri (agribisnis), yaitu: penyedia dan penyalur saprodi, alsintan; (ii) produk pertanian (produk primer/belum diolah); (iii) agroindustri; (iv) pemasaran berbagai produk pertanian; (v) pelayanan publik (storage, perbankan, angkutan, asuransi) (Elizabeth, 2015). Pemasaran produk pertanian umumnya merupakan titik kritis dalam rantai bisnis berbagai produk agribisnis terutama produk agroindustri (Saptana et al, 2005), karena terbatas waktu dan lokasi pelaksanaan serta bergantung peran pedagang pengumpul. Terkait pemasaran, perannya sebagai wadah untuk melakukan aktivitas transaksi (jual/beli) perlu diberdayakan untuk mempermudah stakeholders dalam mengakses dan kemudahan memperoleh barang yang dibutuhkan.

Kebijakan pembangunan dan pengembangan agroindustri di pedesaan terutama untuk mendorong terciptanya keseimbangan struktur perekonomian (Kemenko Ekuin, 2016). Pengembangan agroindustri dimaksudkan berperan dalam penciptaan nilai tambah (value added), penyerapan dan produktivitas tenaga kerja dan pasar (Elizabeth, 2017); perlu disertai oleh program yang langsung menuju ke sasaran (rumah tangga petani sebagai subjek), dimana agroindustriral development dikombinasikan dengan rural development sehingga menjadi satu program pembangunan pedesaan komprehensif, yaitu: "rural-agroindustrial develop- 
ment". Untuk memperbaiki kondisi tersebut diperlukan pengembangan dan pemberdayaan yang dimulai dari masyarakatnya agar menjadi esensial untuk mencapai kesinergisan optimum dalam aktivitasnya di tingkat lokal; membantu peningkatan ke arah industrialisasi; dan memudahkan petani mengembangkan sistem agroindustri (Elizabeth, 2015).

Dalam perencanaan dan pelaksanaan pembangunan pertanian di pedesaan, hendaknya ditekankan perbaikan dan pembenahan ragam agroindustri yang berdayaguna dan berhasilguna serta ke arah peningkatan pendapatan, kesempatan kerja dan berusaha di pedesaan (Herodian, 2006). Sebagai penghela pembangunan pertanian, agroindustri diharapkan mampu menciptakan berbagai produk pertanian dan produk olahannya, mampu memotori industrialisasi pedesaan (Hermanto, 2015. Hermanto et al, 2013), serta mampu menciptakan lapangan kerja dan pendapatan di pedesaan. Beberapa kendala dalam pengembangan agroindustri, meliputi: (i) belum berkembangnya teknologi pengolahan karena masih kecil dan terbatasnya sumber permodalan; (ii) rendahnya kualitas SDM dan belum professional; (iii) sarana dan prasarana belum memadai; (iv) rendahnya jaminan mutu dan kontiniutas (ketersediaan) bahan baku; (v) pemasaran belum berkembang karena produk industri pengolahan pertanian belum memenuhi persyaratan pasar, khususnya pasar internasional; (vi) belum adanya kebijakan riil yang mendorong berkembangnya agroindustri di dalam negeri.

Penguatan teknologi pengolahan produk dengan pemberdayaan dan partisipasi masyarakat tani merupakan salah satu faktor penting dan penunjang dalam pengembangan agroindustri di pedesaan (Hermen, 2015 dalam Elizabeth, 2017), agar program pengembangan teknologi maupun investasi mampu menjadi "mesin penggerak" kemajuan ekonomi yang tangguh di pedesaan (Elizabeth, 2017). Untuk menumbuhkan ekonomi pedesaan perlu upaya memperkuat jaringan sosial masyarakat yang efisien (baik dari aspek struktur/ konfigurasinya), keanggotaan (tingkat partisipasi masyarakat), maupun peranan atau fungsi (pembagian kerja secara organik). Berbagai aspek sosial ekonomi pertanian di pedesaan dan pemasaran produk olahan perlu dibenahi dalam proses dan mendukung pengembangan agroindustri, 


\section{PERTANIAN BIOINDUSTRI MENINGKATKAN DAYASAING PRODUK AGROINDUSTRI \\ DAN PEMBANGUNAN PERTANIAN BERKELANJUTAN \\ Roosganda Elizabeth, Iwan Setiajie Anugrah}

harus mampu berperan dalam peningkatan nilai tambah (value added) produk olahan, penyerapan dan produktivitas tenaga kerja, dan memperluas jangkauan pemasaran melalui kajian deskriptif.

Pelaksanaan bioindustri pertanian berkelanjutan sudah seharusnya dapat memenuhi beberapa kriteria keuntungan, yang meliputi keuntungan: ekonomi, sosial, konservasi dan kelestarian sumberdaya alam (SDA), ekosistem lahan dan kualitas lingkungan yang sehat dan alami secara bijaksana dan berkelanjutan. Sistem pertanian berkelanjutan juga merupakan tulang punggung (back bone) demi terwujudnya kemandirian dan ketahanan pangan. Terkait dengan semakin menyusutnya minyak bumi yang masih menjadi salah satu sumber energi utama, berbagai bahan dan materi berbasis pertanian dapat diolah lebih lanjut untuk.menghasilkan bioenergi pensubstitusi bahan bakar minyak (BBM) dan atau yang ditujukan untuk meningkatkan produksi minyak bumi (misalnya surfaktan dari hasil sintesis minyak sawit) (BPPT, 2013; ESDM, 2013 dalam Hambali et al, 2014).

Berbagai regulasi/kebijakan industrialisasi, terkait agroindustri terutama tanaman pangan, ditempuh untuk memperkuat posisi tawar dan meningkatkan dayasaing berbagai produk olahannya di pasar regional dan internasional (Kemenkeu, 2014). Pengimplementasiannya juga mempertegas bahwa industrialisasi adalah langkah strategis untuk mengolah produk pertanian (agroindustri) sebagai hasil sumberdaya alam strategis dan harus ditempuh dengan memperkuat proses akhir sekaligus awal di sektor agroindustri, serta memperkuat posisi tawar berbagai produk olahan berbasis pertanian tanaman pangan Indonesia, baik di pasar regional maupun di pasar dunia (internasional). Pengimplementasiannya diprediksi sebagai resultante peningkatan dan pengembangan pengelolaan sumberdaya alam. Hal tersebut juga membuat bangsa Indonesia berangsur-angsur bisa melepaskan diri dari jebakan paradox of plenty (kondisi dimana suatu negara yang kaya sumberdaya alam tetapi rakyatnya miskin) (Fauzi, 2014). Dengan demikian, potensi pertanian Indonesia yang luar biasa dapat dimanfaatkan dengan seluas-luasnya untuk mewujudkan kemandirian, kedaulatan, ketahanan pangan dan energi nasional melalui kebijakan implementasi yang 
tepat dan konsisten oleh pemerintah, berkelanjutan serta selalu mengedepankan kelestarian lingkungan dan SDA.

Semakin menipisnya cadangan minyak bumi dan lamanya proses terbentuknya material bahan bakar dari fosil, mengharuskan segera berinovasi menghasilkan energy alternatif dan terbarukan yang telah dihasilkan dari berbagai aplikasi bioindustri. Tercapainya kemandirian dan ketahanan pangan, pemanfaatan SDA dan SDM dalam pelaksanaan program pertanian bioindustri berkelanjutan selain memenuhi kriteria GMP. Pengimplementasiannya seharusnya juga mencakup keuntungan: ekonomi, sosial, kelestarian SDA dan lingkungan (SDGs), secara bijak dan berkelanjutan. Pengembangan agroindustri dalam perspektif pertanian bioindustri mengindikasikan perlunya peningkatan kualitas dan kompetensi SDM dan kelembagaan terkait yang bijak dari aspek ekonomi, sosial dan kelestarian lingkungan (SDGs). Perlunya peran dan pemberdayaan kelembagaan penghasil produk agroindustri berdayasaing, efisiensi dan efektifitas energi alternatif dan terbarukan dengan pengelolaan SDA dan SDM. Perlunya keberpihakan regulasi dan kinerja program pembangunan yang holistik dan terstruktur terkait regulasi, infrastruktur dan kelembagaan lainnya serta tepat: jenis, waktu, jumlah dan sasaran. Pelaksanaan kegiatan agroindustri dan pertanian bioindustri hulu hingga hilir dan keberlanjutannya, yang menghasilkan beragam pangan sehat dan bernilai tambah tinggi dari sumberdaya hayati (SDGs). Dengan menambah pendapatan dan kesejahteraan, para petani diharapkan mampu mewujudkan kemandirian pangan dan energy, ketahanan pangan serta pertanian bioindustri berkelanjutan.

\section{KESIMPULAN DAN IMPLIKASI KEBIJAKAN}

- Upaya meningkatkan produktivitas dan kesejahteraan petani sebagai pelaku usahatani perlu terus dilakukan pemanfaatan bioenergi dan inovasi keberagaman dan pengembangan agroindustri produk olahan berbasis pertanian, sebagai sumber perolehan pendapatan dan kesempatan kerja yang potensial di Indonesia yang dikenal sebagai negara agraris.

- Perlunya dukungan peningkatan dan pengembangan teknologi bioenergi untuk peningkatan produksi dan produktivitas serta kesempatan bekerja dan berusaha (agroindustri 


\section{PERTANIAN BIOINDUSTRI MENINGKATKAN DAYASAING PRODUK AGROINDUSTRI \\ DAN PEMBANGUNAN PERTANIAN BERKELANJUTAN \\ Roosganda Elizabeth, Iwan Setiajie Anugrah}

produk olahan); yang dilakukan secara sinergis optimal dan terintegrasi terkait pelaksanaan program pertanian bioindustri berkelanjutan supaya seluruh stakeholders mempunyai kemauan, kemampuan, kesempatan dan kewenangan untuk berkontribusi nyata dan memperoleh manfaat optimal.

- Perlunya pengembangan usaha bioindustri dan agroindustri, terutama di pedesaan, mengindikasikan adanya peningkatan kualitas dan kompetensi SDM dan tentunya berdampak pada bertambahnya perolehan pendapatan yang disinyalir mampu mewujudkan kemandirian dan ketahanan pangan dan kesejahteraan petani.

- Perlunya keberpihakan dan dukungan pemerintah kepada kelompok tani produk olahan terutama dengan program kebijakan pelatihan dan bimbingan teknologi secara intensif dan berkesinambungan dalam pemanfaatan bioenergi untuk menghasilkan produk olahan, serta untuk mewujudkan penguatan kelompok tani produk olahan dari subsistem hulu (budidaya) sampai dengan subsistem hilir (pemasaran dan menjadi pelaku usaha produk olahan) sesuai dengan konsep value chain market based solution.

- Perlunya keseragaman dan kesepakat bersama/komitmen masing-masing para pemangku kebijakan di tingkat pusat hingga tingkat daerah, sehingga dapat membantu kelancaran dalam koordinasi dan pelaksanaan program kerja di daerah.

- Perlunya pemberdayaan pengelolaan SDA baik dari aspek ekonomi, sosial dan kelestarian lingkungan dengan benar dan bijak, melaksanaan prinsip 6 M (man, money, material, machine, method, management), serta partisipasi seluruh pelaku usaha dan pihak terkait.

- Perlunya berbagai regulasi dan kelembagaan yang mewadahi berbagai kegiatan bioindustri dan agroindustri mulai dari sisi produksi, pengolahan, pemasaran dan keberlanjutannya.

\section{DAFTAR PUSTAKA}

Badan Kebijakan Fiskal. 2012.

Badan Penelitian dan Pengembangan Pertanian. 2005. Prospek dan Arah Pengembangan Agribisnis: Rangkuman Kebutuhan Investasi. Badan Penelitian dan Pengembangan Pertanian Kementerian Pertanian.

Balai Besar Industri Agro Bogor (BBIA. Bogor). 2014. Pengembangan Industri Agro di Indonesia. 
Makalah disampaikan pada Seminar Forum Komunikasi Kelitbangan (FKK) Kementan, Serpong, 14 Mei 2014.

Bahtiar, dan Kindangen, J. G. 2011. Penerapan Rantai Nilai (Value Chain Analysis) dalam Rangka Akselerasi Pembangunan Sektor Pertanian di Sulawesi Utara. Balai Pengkajian Teknologi Pertanian (BPTP) Sulawesi Utara.

Bappenas. 2013. Studi Pendahuluan Rencana Pembangunan Jangka Menengah Nasional (RPJMN) Bidang Pangan dan Pertanian 2015-2019. Bappenas. Jakarta.

Biggs. 1989; Cornwall and Jewkes. 1995; Parkers and Panelli. 2001; dalam: Emma Jakku, Peter Thorburn and Clare Gambley.'Decision Support Systems for Farm Management: A Theoretical Framework from the Sociology of Science and Technology." Tropical Landscapes Program, CSIRO Sustainable Ecosystems, Quuensland Bioscience Precinct, 306 Carmody Road, St Lucia QLD 4067.

http://www.cropscience.org.au/icsc 2004/poster/4/1/1/1219_jakkues.ht m, 5 Januari 2018.

Diana T,S dan Sumarauw J. 2015. Analisis Nilai Tambah Rantai Pasokan Beras di Desa Tatengesan Kecamatan Pusomaen Kabupaten Minahasa Tenggara. Jurnal EMBA Vol.3 No.2 Juni 2015.

Elizabeth. 2018. Akselerasi Agroindustri Dan Nilai Tambah: Faktor Pendukung Pencapaian Dayasaing Produk Dan Percepatan Pembangunan Pertanian Di Indonesia. OJS. Online Jurnal System. UNES (Univ. Ekasakti). Padang. Sumatera Barat.

Elizabeth. 2018a. Akselerasi Pencapaian
Dayasaing Produk Agroindustri Melalui Revitalisasi

Berkesinambungan Implementasi Pemberdayaan Kelembagaan Pertanian. Buku. Puslitbangtan. Kementerian Pertanian. Jakarta.

Elizabeth. R. 2017. Revitalisasi Industri Produk Olahan Dan Pemberdayaan Lembaga Kemitraan Mendukung Peningkatan Pemasaran, Daya Saing Dan Pensejahteraan Petani Pisang. Journal of Agricultural Scienties. UNES. (Universitas Ekasakti). Padang Sumatera Barat. Volume 2. Issue 1. June 2017. ISSN Cetak: 2528-5556. ISSN Online: 2528-6226.

Elizabeth. R. 2017a. Akselerasi Pemberdayaan Dan Peningkatan Kompetensi Dalam Sistem Produksi Untuk Mengatasi Permasalahan Ekonomi Di Indonesia. Volume 2. Issue 1. June 2017. ISSN Cetak: 2528-5556. ISSN Online: 2528-6226.

Elizabeth, R. 2016. Pemberdayaan Petani Dalam Pengelolaan Tanaman Dan Ternak Guna Meningkatkan Kesejahteraan Petani. Prosiding Seminar Nasional Agustus 2016. BPTP Sulawesi Utara. Manado. Badan Litbang Pertanian. Sekretaris Jenderal Pertanian. Kementerian Pertanian.

Elizabeth. R. 2015. Pencapaian Daya Saing Melalui Peningkatan Teknologi Pengolahan, Peningkatan Kelembagaan Dan Pemasaran Produk Pangan Olahan. PERHEPI. Tema: Indonesia Menuju Swasembada Pangan Dalam Tiga Tahun Kedepan: "Tinjauan Konseptual, Teoritis dan Empiris". Kendari, 9 Maret, 2015.

Elizabeth. R. 2014. Mewujudkan Kemandirian Dan Ketahanan Pangan Melalui Revitalisasi Dan 
Pengembangan Infrastruktur Pertanian. Konferensi Nasional XVII dan Kongres XVI PERHEPI. IPB International Convention Center (IICC). Bogor. 28-29 Agustus 2014.

Fauzi Aziz. 2014. Hilirisasi Cermin Politik Industri. Bisnis Indonesia. http://www.neraca.co.id/ bisnisindonesia. (12 Januari 2017)

Hadi P. 2014. Reformasi Kebijakan Penciptaan Nilai Tambah Produk Pertanian Indonesia. Reformasi Kebijakan Menuju Trasformasi Pembangunan Pertanian. Haryono (editor). Badan Litbang Pertanian.

Hambali. E. 2014. Peran Pertanian dalam Membantu Mewujudkan Kemandirian Energi. Semnas Hari Pangan Sedunia (HPS) ke 34. Makassar, 4 November 2014. Pusat Sosial Ekonomi dan Kebijakan Pertanian (PSEKP). Bogor. Kementerian Pertanian. Jakarta.

Hambali, E., B.T.H. Marbun dan M. Rivai. 2014. Esterifikasi Gliserol Hasil Samping Industri Biodiesel Olein Sawit sebagai Water-Based Mud. Buku Penelitian Unggulan. IPB Press.

Hayami, Y. Kawagoe, T dan Morooka, Y. 1987. Agricultural Marketing and Processing in Upland Java; A Perspektif From A Sunda Village.CGPRT No 8. Bogor.

Haryono. 2014. Ketersediaan Teknologi Siap Guna Dalam Pengembangan Sistem Pertanian Bioindustri Berbasis Pangan Lokal Potensial. Semnas Hari Pangan Sedunia (HPS) ke 34. Makassar, 4 November 2014. Pusat Sosial Ekonomi dan Kebijakan Pertanian (PSEKP). Bogor. Kementerian Pertanian. Jakarta.

Hermanto, Reni Kustiari dan Helena J. Purba 2013. Impact of Rice Production Surplus on National and Regional Economies. In Handry, Resosudarmo, B.P., Suryani, Serigar S, Priyarsono, dan A.A. Yusuf (editors). Regional Develeopment, Natural Resources and Public Good in Indonesia during the Global Financial Crisis. Indonesia Regional Science Association. UI-Press.

Hermanto. 2015. General Equilibrium Analysis of the Impact of Climate Change 23 and its Adaptation on Indonesian Agriculture. In Book Economy-Wide Analysis of Climate Change in Southeast Asia: Impact, Mitigation and Trade-off. Published by World Fish (ICLARM) - Economy and Environment Program for Southeast Asia (EEPSEA). Philippines.

Hermen, M. 2015. Bangun Industri Desa Selamatkan Bangsa. IPB Press. Majalah pangan XVI, No. 48 Januari 2007, Hal.: 38-49. Jakarta

Iffan Maflahah. 2010. Analisis Proses Pembuatan Pati Jagung (Maizena) Berbasis Neraca Massa. EMBRYO VOL. 7 NO. 1 JUNI 2010.

Ihalauw. O. 2014. Pertanian-Bioindustri Berbasis Pangan Sagu di Kabupaten Sorong Selatan. Semnas Hari Pangan Sedunia (HPS) ke 34. Makassar, 4 November 2014. Pusat Sosial Ekonomi dan Kebijakan Pertanian (PSEKP). Bogor. Kementan. Jakarta.

John W. and R. Rocha. 2009. Agroindustry Trends, Patterns and Development Impacts. In (edited by) Carlos A. S., D.B. Andrew, S.C. Jenane dan S.M. da-Cruz: Agro- Industries For Development. Published by The Food and Agriculture Organization of the United Nations and The United Nations Industrial 
Development Organization by arrangement with $\mathrm{CAB}$ International

Jumadi, 2008. Pengkajian Teknologi Pengolahan Tortila Jagung. Buletin Teknik Pertanian. 13(2); 73- 74.

Kaniasari, N. 2012. Meningkatkan Nilai Tambah dan Daya Saing Produk Pertanian.

Kasryno, F. 2013. Politik Revitalisasi Pertanian dan Dampak Pelaksanaannya. Dalam Ariani et al. (Eds). Diversifikasi Pangan dan Transformasi Pembangunan Pertanian. Badan Litbang Pertanian, Kementerian Pertanian. Jakarta.

Kementerian Koodinator Bidang Perekonomian. 2016. Outlook Ekonomi Indonesia 2017: Melanjutkan Reformasi: Menjaga Ketahanan dan Memacu Pertumbuhan Ekonomi. Bahan paparan Menteri Koodinator Bidang Perekonomian Republik Indonesia. Jakarta, 10 November 2016.

Kusumawardani MH. 2012. Membuat Rantai Nilai Lebih Berpihak Pada Kaum Miskin: Buku Pegangan Bagi Praktisi Analisis Rantai Nilai. Australian Goverment(AU): Aciar. Ignas K. Lidjang, Amirudin P., H.H.Marawali. 2015. Pendekatan Pengembangan Pertanian Bioindustri Berkelanjutan di NTT. Buku "Perspektif Pengembangan Model Pertanian Bioindustri." Badan Litbang Pertanian. Jakarta. IAARD Press. ISBN 978-602-691632-7.

Liu, H., W. Burkett, and K. Haynes. 2005. Improving Freezing and Thawing Properties of Fly Ash Bricks. Proceedings of The World of Coal Ash, 11-15 April 2005. Kentucky, USA.

Ilham, N. K.S. Indraningsih, Elizabeth.
R. 2018. Kinerja Berbagai Pola Usaha Pembibitan Sapi Lokal Di Beberapa Daerah Pengembangan Sapi Potong. Jurnal. Analisis Kebijakan Pertanian. (AKP). Vol. 15. No. 1. 2017. Hal. 67-82. PSEKP. Bogor. Kementerian Pertanian. Jakarta.

Mahendradatta dan Tawali, 2008. Jagung dan Diversifikasi Produk Olahannya. Masagene Press. Pusat Kajian Makanan Tradisional Universitas Hasanuddin Makassar.

Nurkholis, Sugiarto Nur Rahman, dan Alfons Mau Klau. 2014. Pemanfaatan dan Optimalisasi Sorgum Sebagai Sumber Bahan Energi Alternatif (Bioethanol). Semnas Hari Pangan Sedunia (HPS) ke 34. Makassar, 4 November 2014. Pusat Sosial Ekonomi dan Kebijakan Pertanian (PSEKP). Bogor. Kementan. Jakarta.

"Participatory Monitoring and Evaluation". http://nweb18.world bank.org/ Participatory Monitoring and Evaluation1. 7 Januari 2018

Pretty, J. 1995. "Regenerative Agriculture: Policies and Practise for Sustainability and Selfrelience." London, Earthscan. (dalam: R. Ramirez. "Participatory Learning and Communication Approaches for Managing Pluralism. http://www.fao.org/documents/sho w_cdr.asp?url_file=/DOCREP/W88 27/w8827e08.htm

Qanytah. 2012. Proses Produksi Tepung Jagung, Pembuatan Tepung Jagung. Download:http://jateng.litbang.dept an.go.id/ind/images/Publikasi/artike 1/tepungjagun g.pdf, Diakses tanggal 27 Maret 2017.

Rachmat, M. R. Elizabeth. Supadi. H. Supriyadi. P. U. Hadi. S. Nuryanti. 
2012. Studi Kebutuhan Pengembangan Produk Olahan Pertanian Dalam Rangka Liberalisasi Perdagangan. LHP. PSEKP. Bogor. Badan Litbang Pertanian. Kementerian Pertanian. Jakarta.

Rafki R. 2015. Analisa Hukum UndangUndang Nomor 3 TAHUN 2014 Tentang Perindustrian. Program Pasca Sarjana Fakultas Hukum Universitas Andalas Padang. https://www.academia.edu/1094781 3/ANALISA HUKUM UNDANG UNDANG NOMOR 3 TAHUN 2014_TENTANG_PERINDUSTRI AN (13 Januari 2017).

Ridwan, H. K., A. Ruswandi, Winarno, A. Muharam, dan Hardiyanto. 2008; 2012. Sifat Inovasi dan Aplikasi Teknologi Pengelolaan Terpadu Kebun Jeruk Sehat dalam Pengembangan Agribisnis Jeruk di Kabupaten Sambas, Kalimantan Barat. J. Hort. 18(4):457-465.

Rosman, I. dan M. I. Bahua. 2013. Analisis Rantai Nilai Komoditas Jagung serta Strategi Peningkatan Pendapatan Petani Jagung di provinsi Gorontalo. Universitas Negeri Gorontalo.

Ruslan Krisno. 2014. Penerapan Sistem Pertanian-Biorefinery Terpadu Berbasis Tanaman Nanas PT Great Giant Pineapple (GGP). Semnas Hari Pangan Sedunia (HPS) ke 34. Makassar, 4 November 2014. Pusat Sosial Ekonomi dan Kebijakan Pertanian (PSEKP). Bogor. Kementerian Pertanian. Jakarta.

Suswono. 2013. Sambutan Menteri Pertanian dalam Buku SIPP (Strategi Induk Pembangunan Pertanian) 2015-2045. Kementerian Pertanian. 2014.

Spencer H. and J. Cranfield. 2009. Building the Political Case for
Agro-industries and Agribusiness in Developing Countries. In (edited) Carlos A. S., D.B. Andrew, S.C. Jenane dan S.M. da-Cruz: Agro-Industries For Development. FAO and The United Nations Industrial Development Organization by arrangement with CAB International.

Stringer R. 2009. Value Chain Analysis. Workshop Value Chain Analysis Tanggal 5 -7 Juni 2009 di Mataram NTB: Badan Litbang Pertanian. Subroto, Anggun. 2014. Evaluasi Kinerja Supply Chain Manajemen Pada Produksi Beras Di Desa Panasen Kecamatan Kakas. Jurnal Emba. ISSN 23031174,Vol.2No.3 September. http://ejournal.unsrat.ac.id/index.ph $\mathrm{p} / \mathrm{emba} /$ article/view/5918/545.

Diakses tanggal 1 Oktober 2019. Hal.1584-1591.

Suismono, Rachmat R, Sumantri A dan Tjahjohutomo R. 2013. Kajian Model Agroindustri Padi Berbasis Klaster Study of Cluster-Based Rice Agroindustry Models. PANGAN, Vol. 22 No. 2 Juli 2013.

Sutisna, E. 2015. Perspektif Pengembangan Pertanian Bioindustri di Papua Barat. Buku "Perspektif Pengembangan Model Pertanian Bioindustri." Badan Litbang Pertanian. Jakarta. IAARD Press. ISBN 978-602-6916-32-7.

Wahyunto, S. Ritung, Suparto, dan H. Subagjo. 2005. Sebaran Gambut dan Kandungan Karbon Pulau Sumatera dan Kalimantan. Proyek CCFPI (Climate Cahange, Forest and Peatlands in Indonesia). WI-IP \& WHC.

Widowati, S. 2001. Pemanfaatan hasil samping penggilingan padi dalam menunjang sistem agroindustri di pedesaan. Buletin AgroBio 4(1):3338. Bogor. 
Yudha Hartanto. 2014. Peranan Program Biogas Rumah (BIRU) dalam Mendukung Ketahanan Energi dan Pangan. Semnas Hari Pangan Sedunia (HPS) ke 34. Makassar, 4 November 2014. Pusat Sosial Ekonomi dan Kebijakan Pertanian (PSEKP). Bogor. Kementerian Pertanian. Jakarta. 